\title{
AXIS-SYMMETRIC THERMOELASTICITY TASK OF THE ELASTIC CYLINDER PRESSURE ON THE ELASTIC LAYER TAKING INTO A CCOUNT NON-IDEAL HEAT CONTACT
}

\author{
Bogdan Okrepkyi ${ }^{1}$; Boris Shelestovs'kyi ${ }^{2}$ \\ ${ }^{1}$ Ternopil National Economic University, Ternopil, Ukraine \\ ${ }^{2}$ Termopil Ivan Puluj National Technical University, Ternopil, Ukraine
}

\begin{abstract}
Summary. Solution of the axis-symmetric contact thermoelasticity task of the elastic round isotropic cylinder pressure on the elastic isotropic layer of the finite thickness, taking into account non-ideal heat contact between the cylinder and the layer, has been built. Using the Henkel's method of integral transformation the equation of heat-conductivity and heat-elasticity for the layer was solved, and using the Fourier's method-for the cylinder. The temperature field, displacement and stress in the cylinder are presented by the coefficients, which satisfy the non-finite system of algebraic equations.
\end{abstract}

Key words: elastic cylinder, layer, temperature, non-ideal heat contact, normal contact stresses.

Staement of the problem. Determination of contact strains and stresses taking into account temperature factors is an important task for the investigation of the machine parts and structural elements strength in the areas of their interaction while calculating structures on the elastic basis for effective structure use and base carrying capacity.

Analysis of the available investigations. The influence of temperature factors on the nature of bodies interaction is investigated in papers [1-4]. Particularly, in [2-3] axisymmetric contact problems of thermoelasticity concerning hot circular die pressure on the isotropic halfspace and the layer and in [4] concerning the elastic circular cylinder on the elastic half-space taking into account the nonideal thermal contact are solved. However, the influence of the conditions of nonideal thermal contact between isotropic elastic cylinders and the layer on the magnitude and nature of the normal stresses distribution in the contact area is not sufficiently investigated.

The objective of the paper is to construct the solution of the axisymmetric contact thermoelasticity problem concerning the pressure of elastic isotropic circular cylinder with the flat base on elastic isotropic layer of finite thickness under nonideal thermal contact and to derive formulas for temperature and normal contact stresses determination; to investigate the influence of contact conductivity and Young's modulus of the cylinder and the layer on the distribution of the normal stresses temperature component.

Statement of the problem. Let us suppose the elastic cylinder with length $L$ and a radius $R$ with the flat base is pressed by force $P$ into the elastic layer of finite thickness $H$. The bodies materials are assumed to be isotropic. All points of the cylinder end under the action of external loading are shifted to the same value $\varepsilon$. The surfaces of the cylinder outside the contact area are free from external forces. On the contact area the tangential tensions are $\tau_{r z}=0$.

At the free end of the cylinder the constant temperature $T_{0}$ is set. The thermal contact between the bodies is not ideal. The cylinder lateral surface is heat-insulated. The heat exchange 
with the external environment according to Newton's law takes place on the free layer surfaces. For given assumptions it is necessary to determine the temperature fields and contact normal stresses.

The cylindrical coordinate system $r, \theta, z$ with the center located on the layer surface, and axis $0 z$ is directed along the cylinder axis. All quantities (stresses, displacement, temperature, elastic constants, coefficients of heat conduction and heat exchange, coefficients of linear thermal expansion), related to the layer are marked with the index «1», and those related to the cylinder are without indexes.

Thus, the proposed problem is solved under the following boundary conditions:

$$
\begin{aligned}
& T=T_{0}, \quad(0 \leq r \leq R, z=L) . \\
& \frac{\partial T}{\partial r}=0,(r=R ; 0 \leq z \leq L) \\
& \lambda_{z}^{1} \frac{\partial T^{1}}{\partial z}=\lambda_{z} \frac{\partial T}{\partial z}, \lambda_{z}^{1} \frac{\partial T^{1}}{\partial z}=h_{0}\left(T-T^{1}\right), \quad(0 \leq r \leq R, z=0) \\
& \frac{\partial T^{1}}{\partial z}+H_{2}^{1} T^{1}=0, \quad(R \leq r<\infty, z=0) . \\
& \frac{\partial T^{1}}{\partial z}-H_{1}^{1} T^{1}=0, \quad(0 \leq r \leq \infty, z=-H) . \\
& U_{z}=-\varepsilon, \tau_{r z}=0, \quad(0 \leq r \leq R, z=L) . \\
& \sigma_{r}=0, \tau_{r z}=0, \quad(r=R, 0 \leq z \leq L) . \\
& \tau_{r z}=0, \quad(0 \leq r \leq R, \quad z=0) . \\
& \tau_{r z}^{1}=0, \quad(0 \leq r<\infty, \quad z=0) . \\
& U_{z}=U_{z}^{(1)}, \sigma_{z}=\sigma_{z}^{(1)}, \quad(0 \leq r<R, \quad z=0) . \\
& \sigma_{z}^{1}=0, \quad(R \leq r<\infty, \quad z=0) . \\
& U_{z}^{1}=0, \quad \tau_{r z}^{1}=0, \quad(0 \leq r \leq \infty, \quad z=-H) .
\end{aligned}
$$

Here $\lambda_{z}, \lambda_{z}^{1}-$ are the thermal conductivity coefficients; $H_{1}^{1}, H_{2}^{1}$ are the heat exchange coefficients; $\varepsilon$ is the value of vertical displacement of cylinder points точок; $h_{0}$ is the contact conductivity. 
The solution of the boundary value problems for thermal conductivity and thermal elasticity equations. It is known [5], that in the axisymmetric case, the thermoelastic potential and the temperature field for the isotropic body are determined from the equations

$$
\nabla^{2} \varphi=\alpha_{T} \frac{1+\sigma}{1-\sigma} T, \quad \nabla^{2} T=0
$$

and the temperature stresses and displacements are calculated by the formulas:

$$
\begin{gathered}
U_{z}^{(T)}=\frac{\partial \varphi}{\partial z}, \quad \tau_{r z}^{(T)}=2 \mu \frac{\partial^{2} \varphi}{\partial r \partial z}, \quad \sigma_{z}^{(T)}=-2 \mu\left(\frac{1}{r} \frac{\partial \varphi}{\partial r}+\frac{\partial^{2} \varphi}{\partial r^{2}}\right), \\
\sigma_{r}^{T}=-2 \mu\left(\frac{\partial^{2} \varphi}{\partial z^{2}}+\frac{1}{r} \frac{\partial \varphi}{\partial r}\right),
\end{gathered}
$$

where $\alpha_{T}$ is the coefficient of linear temperature expansion; $\mu, \sigma$ is shear modulus and Poisson ratio.

To determine the temperature field in the layer, let us introduce Hankel transformation of zero order functions $T^{1}(r, z)$

$$
\overline{T^{1}}(\xi, z)=\int_{0}^{\infty} r T^{1}(r, z) J_{0}(\xi r) d r
$$

due to which, according to the second equation (13), we find $T^{1}(\rho, \varsigma)$ through the arbitrary functions $\varphi_{1}(\eta)$ and $\varphi_{2}(\eta)$ :

$$
T^{1}(\rho, \varsigma)=\int_{0}^{\infty}\left[\varphi_{1}(\eta) e^{\eta \zeta}+\varphi_{2}(\eta) e^{-\eta \zeta}\right] J_{0}(\eta \rho) d \eta
$$

where $J_{0}(\eta \rho)$ is Bessel function of the first kind from the actual argument; $\rho=\frac{r}{R}, \xi=z / R, \eta=\xi R$.

The temperature field in the cylinder is found by Fourier method. The general solution is as follows:

$$
\begin{aligned}
T(r, z)=A_{0} z+ & B_{0}+D_{0}\left(r^{2}-r z^{2}\right)+\sum_{k=1}^{\infty} J_{0}\left(\beta_{k} r\right)\left(A_{k} \operatorname{sh} \beta_{k} z+B_{k} \operatorname{ch} \beta_{k} z\right)+ \\
& +\sum_{k=1}^{\infty} I_{0}\left(\gamma_{k} r\right)\left(C_{k} \sin \gamma_{k} z+D_{k} \cos \gamma_{k} z\right),
\end{aligned}
$$

where $A_{k}, B_{k}, C_{k}, D_{k}$ are arbitrary constants; $I_{0}\left(\gamma_{k} r\right)$ is Bessel function of the first kind of the imaginary argument; $\beta_{k}, \gamma_{k}$ are eigen values determined from the boundary conditions.

By known temperature fields, we determine the thermoelastic potentials from the first equation (13), the partial solution of which for the layer and cylinder, relatively, is as follows: 
a) for the layer:

$$
\varphi(r, z)=\frac{1}{2} \frac{1+\sigma}{1-\sigma} \alpha_{T^{1}} \varsigma \int_{0}^{\infty} \frac{1}{\eta}\left[\varphi_{1}(\eta) e^{\eta \varsigma}+\varphi_{2}(\eta) e^{-\eta \varsigma}\right] J_{0}(\eta \rho) d \eta
$$

b) for the cylinder:

$$
\begin{aligned}
& \varphi(r, z)=\frac{1}{6} A_{0} z^{3}+\frac{1}{4} B_{0} r^{2}+\frac{1}{16} C_{0} r^{4}-\frac{1}{6} D_{0} z^{4}+ \\
& +\frac{1}{2} \frac{1+\sigma}{1-\sigma} \alpha_{T} z\left[\sum_{k=1}^{\infty} \frac{J_{0}\left(\beta_{k} r\right)}{\beta_{k}}\left(A_{k} \operatorname{ch} \beta_{k} z+B_{k} \operatorname{sh} \beta_{k} z\right)-\sum_{k=1}^{\infty} \frac{I_{0}\left(\gamma_{k} r\right)}{\gamma_{k}}\left(C_{k} \cos \gamma_{k} z-D_{k} \sin \gamma_{k} z\right)\right]
\end{aligned}
$$

The components of temperature stresses and displacements are calculated by the formulas (14). With formulas for temperature stresses and displacements, it is possible to solve the problem under mechanical boundary conditions. In order to do this, it is necessary to add components of stresses and displacements from the biharmonic potential to the values calculated according to formulas (14) [1].

To satisfy the boundary condition (2) in formula (17) it is necessary to put $D_{0}=0, D_{k}=0, C_{k}=0(k=\overline{1, \infty}) ; \beta_{k}=\mu_{k} / R$, where $\mu_{k}$ are the roots of the equation $J_{1}\left(\mu_{k}\right)=0$;

$$
\gamma_{k}=\frac{k \pi}{R}
$$

The boundary condition (1) taking into account the orthogonality of Bessel functions results in such relations between constants $B_{0}, B_{n}$ and $A_{0}, A_{n}(n=\overline{1, \infty})$.

$$
B_{0}=T_{0}-A_{0} \ell R, \quad B_{n}=-t h \mu_{n} \ell A_{n}, \quad \ell=L / R
$$

Having satisfied the boundary conditions (3-5) taking into account (21) we get the system of integral relations connecting the functions $\varphi_{1}(\eta)$ and $\varphi_{2}(\eta)$ with the coefficients $A_{k}(k=\overline{0, \infty})$ :

$$
\begin{gathered}
\int_{0}^{\infty}\left[\left(h_{0}^{1}+\eta\right) \varphi_{1}(\eta)+\left(h_{0}^{1}-\eta\right) \varphi_{2}(\eta)\right] J_{0}(\eta \rho) d \eta= \\
=h_{0}^{1}\left[T_{0}-A_{0} \ell R-\sum_{k=1}^{\infty} t h \mu_{k} \ell J_{0}\left(\mu_{k} \rho\right) A_{k}\right],(\rho<1) . \\
\frac{\lambda z^{1}}{R} \int_{0}^{\infty} \eta\left[\varphi_{1}(\eta)-\varphi_{2}(\eta)\right] J_{0}(\eta \rho) d \eta=\frac{\lambda z}{R}\left(A_{0} R+\sum_{k=1}^{\infty} \mu_{k} J_{0}\left(\mu_{k} \rho\right) A_{k}\right),(\rho<1) .
\end{gathered}
$$




$$
\begin{gathered}
\int_{0}^{\infty}\left[\left(K_{2}^{1}+\eta\right) \varphi_{1}(\eta)+\left(K_{2}^{1}-\eta\right) \varphi_{2}(\eta)\right] J_{0}(\eta \rho) d \eta=0,(\rho>1) . \\
\int_{0}^{\infty}\left[\left(\eta-K_{1}^{1}\right) e^{-\eta h} \varphi_{1}(\eta)-\left(\eta+K_{1}^{1}\right) e^{\eta h} \varphi_{2}(\eta)\right] J_{0}(\eta \rho) d \eta=0,(0 \leq \rho<\infty),
\end{gathered}
$$

where $h=H / R ; K_{1}^{1}=H_{1}^{1} R, K_{2}^{1}=H_{2}^{1} R, h_{0}^{1}=h_{0} R / \lambda_{z}^{1}$.

Applying the formula of the inverse transformation of the integral Hankel transformation to equation (26) and introducing the notation $\varphi(\eta)=\left(K_{2}^{1}+\eta\right) \varphi_{1}(\eta)+\left(K_{2}^{1}-\eta\right) \varphi_{2}(\eta)$ we get the system of equations respectively to functions $\varphi_{1}(\eta)$ and $\varphi_{2}(\eta)$ having the following solution:

$$
\begin{gathered}
\varphi_{1}(\eta)=\frac{1}{2}\left(\eta+K_{1}^{1}\right) e^{\eta h} \varphi(\eta) / Q(\eta), \quad \varphi_{2}(\eta)=\frac{1}{2}\left(\eta-K_{1}^{1}\right) e^{-\eta h} \varphi(\eta) / Q(\eta) \\
Q(\eta)=\left(\eta^{2}+K_{1}^{1} K_{2}^{1}\right) s h \eta h+\eta\left(K_{1}^{1}+K_{2}^{1}\right) c h \eta h .
\end{gathered}
$$

Substituting the functions $\varphi_{1}(\eta)$ and $\varphi_{2}(\eta)$ (26) into equation (24), we get:

$$
\int_{0}^{\infty} \varphi(\eta) J_{0}(\eta \rho) d \eta=0, \quad(\rho>1) .
$$

The boundary conditions (9), (12) for the stress $\sigma_{z}^{1}(\rho, 0)$ and displacement $U_{z}^{1}(\rho, 0)$ on the layer surface give:

$$
\begin{gathered}
U_{z}^{1}(\rho, 0)=\frac{1+b_{1}^{1}}{b_{1}} R \int_{0}^{\infty}[1-\sigma(2 \eta h)] \phi(\eta) J_{0}(\eta \rho) d \eta-\alpha_{T^{1}} R \delta \int_{0}^{\infty} \frac{1}{\eta} \frac{Q_{2}(\eta) \varphi(\eta)}{Q(\eta) Q_{1}(\eta)} J_{0}(\eta \rho) d \eta \\
\sigma_{z}^{1}(\rho, 0)=2 b_{3}^{1} \int_{0}^{\infty} \eta \phi(\eta) J_{0}(\eta \rho) d \eta \\
R \phi(\eta)=\frac{\eta}{R} F_{1}^{*}(\eta)+b_{1}^{1} F_{2}^{*}(\eta)-\frac{\eta}{R} F_{3}^{*}(\eta)+b_{1}^{1} F_{4}^{*}(\eta), \\
Q_{1}(\eta)=\operatorname{sh} 2 \eta h+2 \eta h, Q_{2}(\eta)=-\left(\eta \operatorname{sh} \eta h \cdot c h \eta h+K_{1}^{1} s h^{2} \eta h+\eta^{2} h\right) s h \eta h, \\
G(2 \eta h)=\frac{1+2 \eta h-e^{-2 \eta h}}{Q_{1}(\eta)}, \quad \delta_{0} \frac{1+\sigma^{1}}{1-\sigma^{1}}\left(1+b_{1}^{1}\right) .
\end{gathered}
$$

Satisfying the boundary conditions for tangential stresses (6-8), we find the problem eigen values $\lambda_{k}$ and $\alpha_{k}$ which are the roots of the corresponding characteristic equations $\sin \lambda_{k} L=0, \quad J_{1}\left(\alpha_{k} R\right)=0$, i. e. 


$$
\lambda_{k}=\frac{k \pi}{L}, \alpha_{k}=\frac{\mu_{k}}{R}
$$

Besides the same conditions result in the following relations between arbitrary constants:

$$
\begin{aligned}
& D_{k}^{*}=0, N_{n}^{*}=- F_{n}^{*} / b_{2}+\frac{1}{2} \frac{1+\sigma}{1-\sigma} \alpha_{T} \frac{b_{1}}{b_{2}} R^{3} \frac{A_{k}}{\mu_{k}^{3}}, E_{k}^{*}=\frac{\ell}{b_{2}} \mu_{k} F_{k}^{*}-\mu_{k}^{*}\left(b_{2}+\mu_{k} \ell c t h \mu_{k} \ell\right)+ \\
&+ \frac{1}{2} \frac{1+\sigma}{1-\sigma} \alpha_{T} b_{1} \frac{R^{3}}{\mu_{k}^{3}}\left[B_{k}\left(\mu_{k} \ell c t h \mu_{k} \ell+1\right)-\frac{b_{1}}{b_{2}} \mu_{k} \ell A_{k}\right], \\
& A_{k}^{*}=-B_{k}^{*}\left[\frac{b_{1}}{b_{2}}+\frac{k \pi}{\ell} I_{0}\left(\frac{k \pi}{\ell}\right) / I_{1}\left(\frac{k \pi}{\ell}\right)\right], k=\overline{1, \infty} .
\end{aligned}
$$

Demanding the fulfillment of the first boundary condition (10) and the boundary condition (11) taking into account (31) we derive the system of integral equations respectively to functions $\phi(\eta)$ and $\varphi(\eta)$ :

$$
\begin{gathered}
\int_{0}^{\infty} \phi(\eta) J_{0}(\eta \rho) d \eta=-\frac{1}{R}\left[2 A_{0}^{*}+\frac{1}{R^{2}} \sum_{k=1}^{\infty}\left(-\frac{1}{b_{1}} F_{k}^{*}+L N_{k}^{*}\right) \mu_{k}^{2} J_{0}\left(\mu_{k} \rho\right)+\frac{1}{2} \frac{1+\sigma}{1-\sigma} \alpha_{T} R \sum_{k=1}^{\infty} \frac{J_{0}\left(\mu_{k} \rho\right)}{\mu_{k}} A_{k}\right]+ \\
+\int_{0}^{\infty} G(2 \eta h) \phi(\eta) J_{0}(\eta \rho)-\alpha_{T^{1}} \delta_{0} \int_{0}^{\infty} \frac{1}{\eta} \frac{Q_{2}(\eta) \varphi(\eta)}{Q(\eta) Q_{1}(\eta)} J_{0}(\eta \rho) d \eta, \quad(0 \leq \rho<1) . \\
\int_{0}^{\infty} \eta \phi(\eta) J_{0}(\eta \rho) d \eta=0, \quad(\rho>1) .
\end{gathered}
$$

Introducing the function $f(t)$ by relationship

$$
\phi(\eta)=\frac{b_{1}^{1}}{1+b_{1}^{1}} \int_{0}^{1} f(t) \cos \eta t d t
$$

equation (33) is satisfied identically, and equation (32) is reduced to Abel equation

$$
\int_{0}^{\rho} \frac{f(t) d t}{\sqrt{\rho^{2}-t^{2}}}=g(\rho),
$$

which solution according to [6] is determined by the formula

$$
f(t)=\frac{2}{\pi} \frac{d}{d t} \int_{0}^{t} \frac{\rho g(\rho) d \rho}{\sqrt{t^{2}-\rho^{2}}}
$$


where $g(\rho)=\frac{2 A_{0}^{*}}{R}+\frac{1}{R^{3}} \sum_{k=1}^{\infty}\left(-\frac{1}{b_{1}} F_{k}^{*}+2 N_{k}^{*}\right) \mu_{k}^{2} J_{0}\left(\mu_{k} \rho\right)+\frac{1}{2} \frac{1+\sigma}{1-\sigma} \alpha_{T} \sum_{k=1}^{\infty} \frac{J_{0}\left(\mu_{k} \rho\right)}{\mu_{k}} A_{k}+$

$$
+\int_{0}^{\infty} G(2 \eta h) \phi(\eta) J_{0}(\eta \rho) d \eta-\alpha_{T^{1}} \delta_{0} \int_{0}^{\infty} \frac{1}{\eta} \frac{Q_{2}(\eta) \varphi(\eta)}{Q(\eta) Q_{1}(\eta)} J_{0}(\eta \rho) d \eta .
$$

Substituting expression (37) to formula (36), taking into account (37), we get Fredholm integral equation of the second kind relatively to the function $f(t)$ :

$$
\begin{gathered}
f(t)=\frac{4}{\pi R} A_{0}^{*}+\frac{2}{\pi R^{3}} \sum_{k=1}^{\infty} \mu_{k}^{2} \cos \mu_{k}+\left(-\frac{1}{b_{1}} F_{k}^{*}+2 N_{k}^{*}\right)+ \\
+\frac{1}{\pi} \frac{1+\sigma}{1-\sigma} \alpha_{T} \sum_{k=1}^{\infty} \frac{\cos \mu_{k} t}{\mu_{k}} A_{k}+\frac{2}{\pi} \int_{0}^{1} f(x) d x \int_{0}^{\infty} G(2 \eta h) \cos x \cos \eta t d \eta- \\
-\frac{2}{\pi} \delta_{0} \alpha_{T^{1}} \int_{0}^{\infty} \frac{1}{\eta} \frac{Q_{2}(\eta) \varphi(\eta)}{Q(\eta) Q_{1}(\eta)} \cos \eta t d \eta, \quad(0 \leq t<1) .
\end{gathered}
$$

Having satisfied the first condition (6) taking into account the conditions of Bessel functions orthogonality, we obtain

$$
\begin{gathered}
-\frac{\varepsilon}{2}=A_{0}^{*}+2 b_{4}^{-1} \ell R B_{0}^{*}+3 \ell R C_{0}^{*}+\frac{1}{4} \ell^{2} R^{2} \frac{1+\sigma}{1-\sigma} \alpha_{T} A_{0}, \\
F_{k}^{*}=b_{2} t h \mu_{k} \ell M_{k}^{*}+\frac{1}{2} \frac{1+\sigma}{1-\sigma} \alpha_{T} R^{3} b_{1} \frac{A_{k}}{\mu_{k}^{3}} .
\end{gathered}
$$

Taking into account equations (31), (39), we satisfy the boundary condition (7) for normal stress $\sigma_{r}$. Multiplying the obtained expression by $\cos \frac{\pi n}{\ell} \varsigma,(n=\overline{0, \infty})$ and integrating it with $\varsigma$ in the range from 0 to $\ell$, taking into account the trigonometric functions orthogonality, we obtain the relation between constants $B_{0}^{*} C_{0}^{*} \mathrm{i}, B_{k}^{*}$ and $\mu_{k}^{*}, A_{0}, A_{k}$.

$$
\begin{gathered}
-2 b_{1} B_{0}^{*}+3 b_{2} C_{0}^{*}=0 \quad B_{n}=-\frac{4}{\pi n \omega_{n}} I_{1}\left(\frac{\pi n}{\ell}\right) \sum_{k=1}^{\infty} \mu_{k}^{4} t_{k, n}^{2} J_{0}\left(\mu_{k} \ell\right) t h \mu_{k} \ell \cdot M_{k}^{*}- \\
-\frac{\ell^{2} R^{3} b_{1}}{\pi^{3}} \frac{1+\sigma}{1-\sigma} \alpha_{T} \frac{I_{1}\left(\frac{\pi n}{\ell}\right)}{n^{3} \omega_{n}}\left\{-2 A_{0} R \frac{\ell^{2}}{\pi^{2} n^{2}}\left[(-1)^{n}-1\right]+\frac{2 \pi^{2} n^{2}}{\ell} \sum_{k=1}^{\infty} t_{k, n}^{2} \mu_{k} J_{0}\left(\mu_{k}\right) U_{k, n} A_{k}\right\},
\end{gathered}
$$

where 


$$
\begin{gathered}
\omega_{k}=-\frac{\ell}{k \pi}\left(2 b_{1}+b_{2}\right) I_{1}^{2}\left(\frac{k \pi}{\ell}\right)+ \\
+\frac{k \pi}{\ell}\left[I_{0}^{2}\left(\frac{k \pi}{\ell}\right)-I_{1}^{2}\left(\frac{k \pi}{\ell}\right)\right], \quad U_{k, n}=1-\frac{(-1)^{n}}{c h \mu_{k} \ell}, \quad t_{k, n}=\frac{1}{\mu_{k}^{2}+\left(\frac{\pi n}{\ell}\right)^{2}} .
\end{gathered}
$$

The contact stresses $\sigma_{z}^{1}(\rho, 0)$ taking into account (29) and (34) are determined by the formula:

$$
\sigma_{z}^{1}(\rho, 0)=\kappa_{0}^{1}\left[\frac{f(1)}{\sqrt{1-\rho^{2}}}-\int_{\rho}^{1} \frac{f^{\prime}(t) d t}{\sqrt{t^{2}-\rho^{2}}}\right], \quad(\rho<1)
$$

where $\kappa_{0}^{1}=\frac{2 b_{1}^{1} b_{3}^{1}}{1+b_{1}^{1}}$

Using the cylinder equilibrium condition $\mathrm{P}=-2 \pi R^{2} \int_{0}^{1} \rho \sigma_{z}^{1}(\rho) d \rho$ and formula (41) taking into account (31), (39), the integral equation (38) is reduced to the form:

$$
\begin{gathered}
f(t)-\frac{2}{\pi} \int_{0}^{1} f(x) d x \int_{0}^{\infty} G(2 \eta h) \cos \eta x\left(\cos \eta t-\frac{\sin \eta}{\eta}\right) d \eta+ \\
+\frac{2 \delta_{0}}{\pi} \alpha_{T^{1}} \int_{0}^{\infty} \frac{1}{\eta} \frac{Q_{2}(\eta) \varphi(\eta)}{Q(\eta) \varphi_{1}(\eta)}\left(\cos \eta t-\frac{\sin \eta}{\eta}\right) d \eta+ \\
+\frac{2}{\pi R^{3}} \frac{1+b_{1}}{b_{1}} \sum_{k=1}^{\infty} \mu_{k}^{2} t h \mu_{k} \ell\left(\cos \mu_{k} t-\frac{\sin \mu_{k}}{\mu_{k}}\right) \mathrm{M}_{k}^{*}=-\frac{\mathrm{P}}{2 \pi R^{2} \kappa_{0}^{1}},(0 \leq t<1) .
\end{gathered}
$$

By satisfying the second boundary condition (10) and integrating the resulting expression on $\rho$ multiplied by $\rho$, and $\rho J_{0}\left(\mu_{n \rho}\right)$ in the range from 0 to 1 taking into account Bessel functions orthogonality conditions, we get the relations between the constants $B_{0}^{*}, C_{0}^{*}, M_{k}^{*}, A_{0}, A_{k} \quad(k=\overline{1, \infty})$ and the function $f(t)$ :

$$
\begin{gathered}
\kappa_{0}^{1} \int_{0}^{1} f(t) d t=2 b_{3}\left(4 b_{1}+3 b_{2}\right) B_{0}^{*}+3 b_{3}\left(2 b_{1}+b_{2}\right) C_{0}^{*}+\frac{1+\sigma}{1-\sigma} \alpha_{T} \mu \ell R A_{0}=-\frac{\mathrm{P}}{2 \pi R^{2}}, \\
\kappa_{0}^{1} \int_{0}^{1} f(t) \cos \mu_{n} t d t=\frac{b_{3}}{R^{3}} \mu_{n}^{3} J_{0}^{2}\left(\mu_{n}\right) \frac{s h 2 \mu_{n} \ell+2 \mu_{n} \ell}{s h 2 \mu_{n} \ell} \mu_{0}^{*-} \\
-\frac{16 b 3 \pi^{3}}{\ell^{4} R^{3}} \mu_{n}^{2} J_{0}^{2}\left(\mu_{n}\right) \sum_{k=1}^{\infty} \frac{t_{n, k}^{2} k^{3} I_{1}^{2}\left(\frac{k \pi}{\ell}\right)}{\omega_{k}} \times \sum_{m=1}^{\infty} \mu_{m}^{4} t_{m, k}^{2} J_{0}\left(\mu_{m}\right) t h \mu_{m} \ell \cdot M_{m}^{*}-\frac{4 \pi}{\ell^{2}} \frac{1+\sigma}{1-\sigma} \alpha_{T} \mu \times
\end{gathered}
$$




$$
\begin{gathered}
\times \mu_{n}^{2} J_{0}^{2}\left(\mu_{n}\right)\left\{-2 A_{0} R \frac{\ell^{2}}{n^{2}} \sum_{k=1}^{\infty} \frac{t_{n, k}^{2} I_{1}^{2}\left(\frac{k \pi}{\ell}\right)}{k \omega_{k}}\left[(-1)^{k}-1\right]+\right. \\
\left.+\frac{2 \pi^{2}}{\ell^{2}} \sum_{k=1}^{\infty} \frac{t_{n, k}^{2} k^{3} I_{1}^{2}\left(\frac{k \pi}{\ell}\right)_{k}^{\infty}}{\omega_{k}} t_{m=1}^{2} \mu_{m} J_{0}\left(\mu_{m}\right) \times\left[1-\frac{(-1)^{k}}{c h \mu_{m} \ell}\right] A_{m}\right\}+ \\
+\frac{1+\sigma}{1-\sigma}(1-2 \sigma) \alpha_{T} t h \mu_{n} \ell J_{0}^{2}\left(\mu_{n}\right) A_{n} .
\end{gathered}
$$

In order to determine the function $\varphi(\eta)$ we extend the equation (27) to the entire interval $(0 \leq \rho<\infty)$

$$
\int_{0}^{\infty} \varphi(\eta) J_{0}(\eta \rho) d \eta=\bigcup(1-\rho) \mathrm{X}(\rho), \quad(0 \leq \rho<\infty),
$$

here $U(x)$ is Heaviside function; $\mathrm{X}(\rho)$ is unknown function taking in the form

$$
\mathrm{X}(\rho)=T_{0}\left\{a_{0}+\sum_{k=1}^{N} a_{k} J_{0}\left(\mu_{k} \rho\right)\right\}, \quad(0 \leq \rho<1),
$$

where $a_{k}(k=\overline{0, N})$ are unknown coefficients to be defined; value $N$ is chosen from the condition of satisfying the desired accuracy of the problem solution.

Applying to both parts of equation (45) the formula of the inversion of integral Hankel transformation, we derive the function $\varphi(\eta)$ through unknown coefficients $a_{k}$ :

$$
\varphi(\eta)=T_{0}\left\{a_{0} J_{1}(\eta)+\eta^{2} J_{1}(\eta) \sum_{k=1}^{N} \frac{a_{k} J_{0}\left(\mu_{k}\right)}{\eta^{2}-\mu_{k}^{2}}\right\} .
$$

Substituting the function $\varphi(\eta)$ (47) into the integral equations (22), (23), (38) taking into account the notations (26), we come to the relations connecting the function $f(t)$ and the coefficients $a_{k}(k=\overline{0, \infty}), a_{k}(k=\overline{0, N})$ :

$$
\begin{aligned}
& T_{0} \sum_{k=1}^{N} a_{k} \alpha_{k}^{(1)}(\rho)+\frac{A_{0} R}{\Delta_{0}}+\sum_{k=1}^{\infty} \frac{J_{0}\left(\mu_{k} \rho\right)}{\Delta_{k}} A_{k}=h_{0}^{1} T_{0}, \quad(\rho<1), \\
& \frac{\lambda_{z}^{1}}{\lambda_{z}} T_{0} \sum_{k=0}^{N} a_{k} \alpha_{k}^{(2)}(\rho)-A_{0} R-\sum_{k=1}^{\infty} \mu_{k} J_{0}\left(\mu_{k} \rho\right) A_{k}=0, \quad(\rho<1) .
\end{aligned}
$$


Multiplying both part of the equations (48), (49) by $\rho$ and $\rho J_{0}\left(\mu_{n} \rho\right)$ and integrating them by $\rho$, in the range from 0 to 1 taking into account Bessel functions orthogonality, we get the system of linear algebraic equations respectively to unknown $a_{k}, X_{k}^{(1)}, X_{k}^{(2)}, y_{k}^{(1)}, y_{k}^{(2)}(k=\overline{0, N})$. To calculate the temperature fields in the cylinder, we have the following formulas:

a) cylindrical area $(0 \leq \rho<1,0 \leq \varsigma \leq \ell)$

$$
T(\rho, \varsigma)=T_{0}\left\{1+2(\varsigma-\ell) \frac{\lambda_{z}^{1}}{\lambda_{z}} \sum_{k=0}^{N} \alpha_{0, k}^{(2)} a_{k}+2 \frac{\lambda_{z}^{1}}{\lambda_{z}} \sum_{k=0}^{N} a_{k} \sum_{m=1}^{\infty} \frac{s h \mu_{m}(\varsigma-\ell) \alpha_{m, k}^{(2)}}{c h \mu_{m} \ell J_{0}^{2}\left(\mu_{m}\right)}\right\} \mu_{m},
$$

b) sphere $(-h \leq \varsigma \leq 0,0 \leq \rho<\infty)$

$$
\begin{aligned}
& T^{1}(\rho, \varsigma)=T_{0}\left\{a_{0}\left[\left(\frac{1+K_{1}^{1}(h+\varsigma)}{K_{1}^{1} K_{2}^{1} h+K_{1}^{1}+K_{2}^{1}}\right)+2 \sum_{m=1}^{\infty} \frac{P_{1}^{*}\left(y_{m}, \varsigma\right)}{Q^{\prime}\left(i y_{m}\right)}\left(\begin{array}{c}
K_{1}\left(y_{m}\right) I_{0}\left(y_{m} \rho\right) \\
-K_{0}\left(y_{m} \rho\right) I_{1}\left(y_{m}\right)
\end{array}\right)\right]+\right. \\
& \left.+\sum_{k=1}^{N} a_{k}\left[\left(\begin{array}{c}
\frac{P_{1}\left(\mu_{k}, \varsigma\right) J_{0}\left(\mu_{k} \rho\right)}{Q\left(\mu_{k}\right) J_{0}\left(\mu_{k}\right)} \\
0
\end{array}\right)+2 \sum_{m=1}^{\infty} \frac{y_{m}^{2} P_{1}^{*}\left(y_{m}, \varsigma\right)}{\left(y_{m}^{2}+\mu_{k}^{2}\right) Q^{\prime}\left(i y_{m}\right)} \times\left(\begin{array}{c}
K_{1}\left(y_{m}\right) I_{0}\left(y_{m} \rho\right) \\
-K_{0}\left(y_{m} \rho\right) I_{1}\left(y_{m}\right)
\end{array}\right)\right]\right\}, \\
& P_{1}(x, \varsigma)=x \operatorname{ch} x(h+\varsigma)+K_{1}^{1} \operatorname{sh} x(h+\varsigma), \quad P_{1}^{*}\left(y_{m, \varsigma}\right)=y_{m} \cos y_{m}(h+\varsigma)+K_{1}^{1} \sin y_{m}(h+\varsigma) .
\end{aligned}
$$

At $0 \leq \rho<1$ the upper expression in round parentheses is taken as multiplier, at $\rho>1-$ the lower one.

In order to determine the contact normal stresses $\sigma_{z}^{1}(\rho, 0)$ we get the following expression:

$$
\begin{gathered}
\sigma_{z}^{1}(\rho, 0)=\sigma_{z}^{\rho}(\rho, 0)+\sigma_{z}^{\left(T^{1}\right)}(\rho, 0) \\
\sigma_{z}^{(P)}(\rho, 0)=-\frac{0,5 P}{\pi R^{2}} \frac{1}{\sqrt{1-\rho^{2}}}\left[X_{0}^{(1)}+\frac{1}{\rho} \sum_{k=1}^{N_{1}}(-1)^{k}(2 k+1) T_{2 k+1}(\rho) X_{k}^{1}\right] \\
\sigma_{z}^{\left(T^{1}\right)}(\rho, 0)=\alpha_{T^{1}} T_{0} \frac{\kappa_{0}^{1}}{\sqrt{1-\rho^{2}}}\left[X_{0}^{2}+\frac{1}{\rho} \sum_{k=1}^{N_{1}}(-1)^{k}(2 k+1) X_{k}^{(2)} T_{2 k+1}(\rho)\right]
\end{gathered}
$$

where $\kappa_{0}^{1}=\frac{E^{1}}{2\left[1-\left(\sigma^{1}\right)^{2}\right]} ; \quad T_{2 k+1}(\rho)$ is Chebyshev function; $\sigma_{z}^{(\rho)}(\rho, 0)$ is power stress component, $\sigma_{z}^{(T)}(\rho, 0)$ is temperature stress component.

In the case $h=\infty$, we obtain the solution of the problem [4]. The solution of both temperature and thermoelastic ones is reduced to the determination of some constants from infinite systems of linear algebraic equations, through which the temperature fields are located at any point of the cylinder and the layer. The given equation systems are quasi-regular with all 
possible ratios of thermophysical and elastic characteristics of the bodies. Taking this into account, the solution is found by the method of reduction from truncated systems. For numerical calculations the systems of 30 linear algebraic equations with 30 unknowns were solved.

The distribution of the dimensionless temperature $\alpha_{1}=\frac{T}{T_{0}}$ along the dimensionless coordinate $\rho$ at $\frac{\lambda_{z}^{1}}{\lambda_{z}}=0.1 ; \ell=2 ; h=2, k_{1}=\infty, k_{2}=0.5$ is shown in Fig. 1. Fig. 2 and 3 represent the distribution of dimensionless normal stress $\alpha_{2}=\frac{\sigma_{z}^{(T)}}{\alpha_{T} T_{0} E}$ at $\frac{\sigma_{T}}{\alpha_{T^{1}}}=1 ; \frac{\lambda z}{\lambda_{z}^{1}}=0.1 ; \sigma=\sigma^{1}=0.3$.

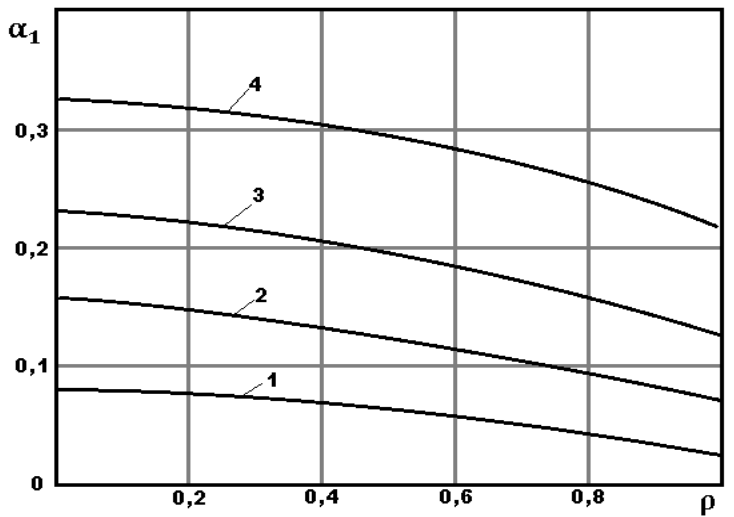

Figure 1. Temperature distribution for different values of contact conductivity, curves: $1-h_{0}^{1}=0.12-h_{0}^{1}=1$;

$$
3-h_{0}^{1}=5 ; 4-h_{0}^{1}=\infty
$$

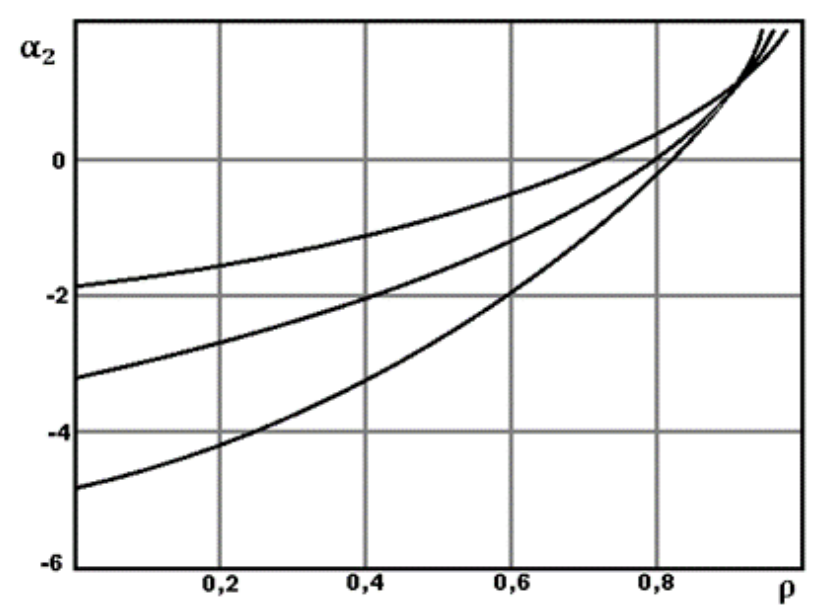

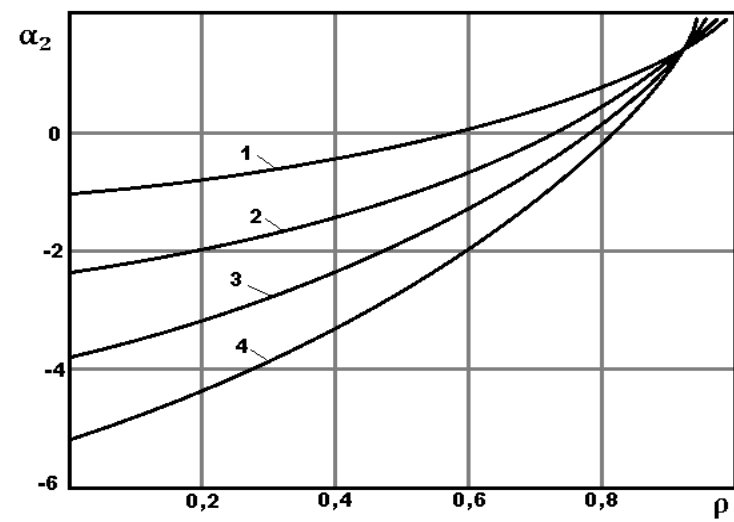

Figure 2. Temperature component distribution of the contact normal stresses for different values of the young's modulus relation $\delta=E / E^{1}$; curves: $1-\delta=0.5 ; 2-\delta=1 ; 3-\delta=2$

Figure 3. Temperature component distribution of the contact normal stresses for different values of the contact conductivity, curves: $1-h_{0}^{1}=0.8 ; 2-h_{0}^{1}=1 ; 3-h_{0}^{1}=5$; $4-h_{0}^{1}=\infty$. 
Conclusions. While pressing the elastic cylinder into the elastic layer, the nonideal thermal contact between the cylinder and the layer significantly affects the nature of the distribution of the temperature components of normal contact stresses, in the same way as it is in the corresponding problem [7].

\section{References}

1. Grilickij D. V., Kizyma YA. Osesimmetrichnye kontaktnye zadachi teorii uprugosti i termouprugosti. L'vov:Vishcha shkola.-Izd. pri L'vovskom universitete, 1981. 135 p. [In Russian].

2. Okrepkyi B. S., Shelestovska M. Tysk tsylindrychnoho kruhovoho shtampa na pruzhnyi pivprostir z urakhuvanniam neidealnoho teplovoho kontaktu. Visnyk TNTU. 2006. No 3, P. 26-33. [In Ukrainian].

3. Okrepkyi B. S. Shelestovska M. Tysk tsylindrychnoho kruhovoho shtampa na pruzhnyi shar z urakhuvanniam neidealnoho teplovoho kontaktu. Visnyk TNTU. 2011. Vol. 16. No. 2. P. 42-52. [In Ukrainian].

4. Okrepkyi B. S., Shelestovska M. Osesymetrychna kontaktna zadacha termopruzhnosti pro tysk pruzhnoho tsylindra na pruzhnyi pivprostir z urakhuvanniam neidealnoho teplovoho kontaktu. Visnyk Ternopilskoho derzhavnoho tekhnichnoho universytetu. 2014. No 2. P. 65-76. [In Ukrainian].

5. Kovalenko A. D. Osnovy termouprugosti. Kiev: Nauk. dumka, 1970. 304 p. [In Russian].

6. Uitteker E. T., Vatson D. Kurs sovremennogo analiza. M.: Fizmat, 1963. 343 p. [In Russian].

7. Kizyma YA. N. Davlenie uprugogo cilindra na uprugij sloj konechnoj tolshchiny. Izd. AN SSSR, MTT, 1972. No. 3 [In Russian].

8. Myhovych F. M., Okrepkyi B. Obchyslennia hrup nevlasnykh intehraliv, yaki mistiat funktsii Besselia Iho rodu. Zbirnyk naukovykh prats Akademii nauk Ukrainy, K., 1995. No. 8. P. 133-137. [In Ukrainian].

\section{Список використаної літератури}

1. Грилицкий Д. В., Кизыма Я. Осесиметричные контактные задачи теории упругости и термоупругости. Львов: Вища школа. Изд.-во при Львовском университете, 1981. 135 с.

2. Окрепкий Б. С., Шелестовська М. Тиск циліндричного кругового штампа на пружний півпростір 3 урахуванням неідеального теплового контакту. Вісник ТНТУ. 2006. № 3. С. 26-33.

3. Окрепкий Б. С., Шелестовська М. Тиск циліндричного кругового штампа на пружний шар 3 урахуванням неідеального теплового контакту. Вісник ТНТУ. 2011. Т. 16. № 2. С.42-52.

4. Окрепкий Б. С., Шелестовська М. Осесиметрична контактна задача термопружності про тиск пружного циліндра на пружний півпростір з урахуванням неідеального теплового контакту. Вісник ТДТУ. 2014. № 2. С. 65-76.

5. Коваленко А. Д. Основы термоупругости. Киев: Наук. думка, 1970. 304 с.

6. Уиттекер Э. Т., Ватсон Д. Курс современного анализа. М.: Физмат, 1963. 343 с.

7. Кизыма Я. М. Давление упругого цилиндра на упругий слой конечной толщины. Изв. АН СССР. МTT. 1972. № 3.

8. Мигович Ф. М., Окрепкий Б. Обчислення групи невласних інтегралів, які містять функції Бесселя І-го роду. Збірник наукових праць Академії наук України. К. 1995. № 8. С. 133-137. 
УДК 539.3

\title{
ОСЕСИМЕТРИЧНА КОНТАКТНА ЗАДАЧА ТЕРМОПРУЖНОСТІ ПРО ТИСК ПРУЖНОГО ЦИЛІНДРА НА ПРУЖНИЙ ШАР 3 УРАХУВАННЯМ НЕІДЕАЛЬНОГО ТЕПЛОВОГО КОНТАКТУ
}

\author{
Богдан Окрепкий'; Борис Шелестовський ${ }^{2}$ \\ ${ }^{1}$ Тернопільський національний економічний університет, \\ Тернопіль, Україна \\ ${ }^{2}$ Тернопільський наџіональний технічний університет ім. І. Пулюя, \\ Тернопіль, Україна
}

\begin{abstract}
Резюме. Визначення контактних напружень із урахуванням температурних факторів $\epsilon$ важливим завданням для дослідження міџності деталей машин і елементів конструкцій у місиях їхньої взаємодії при розрахунку конструкиї на пружній основі для раџіонального використання матеріалу конструкиії $і$ несучої здатності основи. Побудовано розв'язок осесиметричної контактної задачі термопружності про тиск пружного кругового ізотропного ичліндра на пружний ізотропний шар скінченої товщини з урахуванням неідеального теплового контакту між ичиліндром і шаром. Усі точки тория ичиліндра під дією зовнішнього навантаження змішуються на однакову величину. Поверхні шару й циліндра зовні площуаки контакту вільні від зовнішніх зусиль. Дотичні напруження в зоні контакту дорівнюють нулю. На вільному торичі ичиліндра задана постійна температура. Бічна поверхня теплоізольована, а на вільних поверхнях шару здійснюється теплообмін за законом Ньютона. Тепловий контакт між тілами припускається неідеальним. При заданих припущеннях розвинено метод визначення температурних полів у ичиліндрі й шарі, а також нормальних контактних напружень. За допомогою методу інтегрального перетворення Ганкеля розв'язано рівняння теплопровідності й термопружності для шару, а методом Фур'є - для ичиліндричної області. Температурне поле, переміщення й напруження 8 ізотропному шарі зображено невласними інтегралами з невідомими функціями, які знаходяться 3 граничних умов задачі. Температурне поле, переміщення й напруження подано через невідомі коефіцієнти, які визначаються з нескінченних систем лінійних алгебраїчних рівнянь. Задоволення граничних умов задачі призводить до системи інтегральних рівнянь, які зв'язують невідомі функиії з коефіиієнтами, щзо характеризують температурне поле. Як результат, отримано інтегральне рівняння Фредгольма II-го роду відносно функцій, через які виражені нормальні контактні напруження в шарі. Інтегральне рівняння Фредгольма II-го роду розв'язано числовим методом зведенням до системи лінійних алгебрайчних рівнянь. Проведено числові розрахунки для знаходження температури й температурної складової нормального напруження в шарі у зоні контакту для різних значень контактної провідності, а також температурної складової нормального напруження для різних значень модулів Юнга ичиліндра і шару. Числові результати й аналіз розв'язку показують, щчо при контактній взаємодії пружного циліндра $і$ шару неідеальний тепловий контакт значно впливає на розподіл температурної складової нормального напруження в зоні контакту.
\end{abstract}

Ключові слова: пружний цииліндр, шар, температура, неідеальний тепловий контакт, нормальні контактні напруження. 